\title{
Incidence of inflammatory bowel disease in northern France (1988-1990)
}

\author{
C Gower-Rousseau, J-L Salomez, J-L Dupas, R Marti, M-C Nuttens, A Votte, \\ M Lemahieu, B Lemaire, J-F Colombel, A Cortot
}

women and 6.5 for men. This first French prospective study has shown an incidence rate for Crohn's disease comparable with that seen in north European studies but lower than that seen for ulcerative colitis. These results could be related to the different environmental factors or the genetic background of the population studied, or both.

(Gut 1994; 35: 1433-1438)

Inflammatory bowel diseases (IBD) including Crohn's disease and ulcerative colitis are among the most serious and perplexing of digestive diseases. Their pathophysiology remains poorly understood but it is currently accepted that both environmental and genetic factors interact in the occurrence of these diseases. ${ }^{1-14}$ In this regard it is important to detect geographical variations in the incidence of IBD as this can help to identify some of the factors leading to an increased or decreased incidence of IBD. In fact a north-south gradient has for long been suspected in Europe and North America. In the USA only a hospital based study has supported such a gradient. ${ }^{15}$ In Europe a European Community supported population based study was started in 1991 aimed at comparing the incidence of IBD in northern and southern European countries. France is a transition country between both parts of Europe. Northern France is close to Belgium, the Netherlands, Luxembourg, Germany, and England. Its location would anticipate high incidences of ulcerative colitis and Crohn's disease comparable with the figures reported in the Netherlands and England. Therefore, to find out how France compares, as far as IBD incidence is concerned, we undertook the first population based study in northern France (Nord-Pas de Calais and Somme Departements) in 1988. We report on the first three years of registration.

\section{Methods}

POPULATION

The northern part of France has 4514055 inhabitants (1990 National Population census). The study area was divided between three Departements: (a) Nord with 2532589 inhabitants and a population density of $445 / \mathrm{km}^{2}$; (b) Pas de Calais with 1433536 inhabitants and a population density of 210 ; (c) The Somme Departement with 547930 inhabitants and a population density of 89 . 
There were both urban and rural populations in these areas (ratio urban/rural $=8.4$ in Nord, 4.1 in Pas de Calais, and 1.2 in Somme). This region is a well defined geographical entity bordering Belgium on the north and the North Sea on the west (Fig 1). The population is stable - that is, the percentages of population moving per year out of each Departement were 0.8 for Nord, 0.9 for Pas de Calais, and 1.2 for Somme (French National Statistical Institute).

This prospective study started on 1 January 1988. Only patients who had been resident in the defined study region at the time of diagnosis of their disease were included. Among students, short term workers, fishermen, and members of the armed forces only those who were domiciliated in the study area were included. The study was realised through the gastroenterologists of the three Departements. Before the study began, all the gastroenterologists (125 in total with 108 in private and 17 in hospital practice) of the three Departements were informed about the methods and the aims of this work, both by letter and by meetings. Each gastroenterologist reported on any patient consulting for the first time with clinical symptoms compatible with IBD and was contacted by phone at least three times a year by an interviewer practitioner. This interviewer went to the gastroenterologist's consulting room and collected the data from the charts in a standardised questionnaire for each new case. The main data collected were: age, sex, year of diagnosis, interval between onset of symptoms and the diagnosis, clinical, radiological, endoscopic, and histological findings at the time of diagnosis.

\section{DIAGNOSTIC CRITERIA}

Patients with positive stool cultures, neoplastic disease, who had received antibiotic or nonsteroidal anti-inflammatory drug treatment, or both, within the month before the onset of bowel symptoms were excluded. The questionnaires were assessed in a blind manner by two independent expert gastroenterologists. A final diagnosis of Crohn's disease, ulcerative colitis, or ulcerative proctitis was made and recorded as definite, probable, or possible. The following criteria were used:

Definite Crohn's disease - Presence of epithelial granulomas with giant Langhans' type cells at examination of biopsy or surgical specimen irrespective of the duration of clinical symptoms.

Probable Crohn's disease - (1) Lesions in the large bowel without involvement of the small bowel and the presence of at least three of four diagnostic criteria: (a) case history of diarrhoea or abdominal pain for six weeks or longer, or both, (b) radiological or endoscopic findings, or both, with segmental lesions of cobblestone appearance or stenosis in the large bowel, or both; (c) histological findings compatible with Crohn's disease; (d) presence of fistulas or abscesses, or both, in relation to the intestinal lesions. (2) Lesions in the small bowel with or without involvement of the colon and irrespective of the duration of clinical symptoms, the presence of at least two of the above four criteria.

Possible Crohn's disease - (1) Lesions in the large bowel without involvement of the small bowel and the presence of two of the above four criteria. (2) Lesions in the small bowel with or without involvement of the colon and irrespective of the duration of clinical symptoms, the presence of one of the above four criteria.

Definite ulcerative colitis - (1) Case history of diarrhoea or bleeding, or both, for six weeks or longer and at least two of three diagnostic criteria: (a) typical endoscopic findings including granulated, friable mucosa or ulcerations, or both, of the surface mucosa; (b) typical radiological findings including ulcerations, narrowing, and shortening of the colon; (c) typical histological findings at examination of biopsy surgical or necroptic specimens. (2) Surgical or necroptic specimens, macroscopically typical of ulcerative colitis with typical histological findings, irrespective of the duration of clinical symptoms.

Probable ulcerative colitis - (1) Case history of diarrhoea or bleeding, or both, for six weeks or longer and one of the three above criteria. (2) Case history of six weeks or longer of digestive symptoms without diarrhoea and bleeding and two of the three above criteria. (3) Surgical or necroptic specimens, macroscopically typical of ulcerative colitis with no typical histological findings.

Possible ulcerative colitis - Typical case history of more than six weeks but with no morphological and histological findings compatible with the diagnosis.

Definite, probable, and possible ulcerative proctitis were defined according to the same criteria as ulcerative colitis, but with the macroscopic evidence that the sigmoid was normal above the rectum. The rectosigmoid junction was arbitrarily estimated at $20 \mathrm{~cm}$ from the anal margin.

Patients with a case history of chronic colitis compatible with both the diagnosis of Crohn's disease or ulcerative colitis were defined as unclassifiable chronic colitis.

Patients with a case history of colitis of less than six weeks were classified as acute colitis.

\section{QUALITY ASSURANCE PROCEDURES}

The steering committee of the study included five academic gastroenterologists, two academic epidemiologists, one private gastroenterologist, and three interviewer practitioners. This committee established written instructions for the interviewer practitioners for filling in the questionnaire correctly. It also set up a framework to help the expert gastroenterologists in their final diagnosis. The committee met every three months. The aim of these meetings were, by the means of test cases, to verify that the protocol was accurately followed by all interviewer practitioners and to minimise interexpert variations.

To validate the completeness of the case collection through the gastroenterologists, we 
TABLE I Annual incidence of Crohn's disease and ulcerative colitis in northern France by Departement and sex given as the mean of three consecutive years (1988-1990)

\begin{tabular}{|c|c|c|c|c|c|c|c|c|}
\hline & \multicolumn{2}{|l|}{ Nord } & \multicolumn{2}{|c|}{ Pas de Calais } & \multicolumn{2}{|l|}{ Somme } & \multicolumn{2}{|l|}{ Total } \\
\hline & Male & Female & Male & Female & Male & Female & Male & Female \\
\hline $\begin{array}{l}\text { Crohn's disease } \\
\text { Number } \\
\text { Age adjusted incidence } \\
\text { SEM } \\
\text { Ulcerative colitis }\end{array}$ & $\begin{array}{l}123 \\
3 \cdot 2 \\
0 \cdot 72\end{array}$ & $\begin{array}{l}204 \\
5 \cdot 1 \\
0 \cdot 89\end{array}$ & $\begin{array}{l}122 \\
5 \cdot 7 \\
1.36\end{array}$ & $\begin{array}{c}129 \\
5 \cdot 9 \\
1 \cdot 30\end{array}$ & $\begin{array}{l}42 \\
5 \cdot 0 \\
1 \cdot 74\end{array}$ & $\begin{array}{l}54 \\
7 \cdot 0 \\
2 \cdot 18\end{array}$ & $\begin{array}{l}287 \\
4 \cdot 2 \\
0 \cdot 64\end{array}$ & $\begin{array}{l}387 \\
5 \cdot 6 \\
0 \cdot 71\end{array}$ \\
\hline $\begin{array}{l}\text { Number } \\
\text { Age adjusted incidence } \\
\text { SEM }\end{array}$ & $\begin{array}{c}137 \\
3 \cdot 4 \\
0 \cdot 79\end{array}$ & $\begin{array}{l}121 \\
2 \cdot 9 \\
0 \cdot 65\end{array}$ & $\begin{array}{l}92 \\
4 \cdot 0 \\
1 \cdot 07\end{array}$ & $\begin{array}{l}73 \\
3 \cdot 2 \\
1 \cdot 03\end{array}$ & $\begin{array}{l}35 \\
3.9 \\
1.51\end{array}$ & $\begin{array}{l}8 \\
0 \cdot 9 \\
0 \cdot 59\end{array}$ & $\begin{array}{l}264 \\
3 \cdot 6 \\
0 \cdot 60\end{array}$ & $\begin{array}{l}202 \\
2 \cdot 8 \\
0 \cdot 52\end{array}$ \\
\hline
\end{tabular}

undertook a one year validation study in the Somme Departement in 1989. All general practitioners $(n=498)$ and radiologists, histopathologists, surgical, and paediatric specialists $(n=36)$ received a questionnaire for notifying incident cases of IBD. If they did not reply, they were contacted by phone. All specialists and 450 of 498 general practitioners $(91 \%)$ replied. In total, 85 cases were notified by these practitioners. In contrast, the recording system through the gastroenterologists notified only 82 cases. The three 'missing' cases were declared by two pathologists and one general practitioner (one possible ulcerative colitis, one possible Crohn's disease, and one probable ulcerative proctitis). These patients had actually consulted a gastroenterologist who had forgotten to declare their cases to the interviewer practitioner. Thus the completeness of our case collection was $96 \cdot 5 \%$.

\section{INCIDENCE CALCULATIONS}

Age adjusted incidence rates were calculated for the combined group of definite and probable cases. Possible cases as well as acute colitis were not included in the calculation of incidence rates to compare our data with those of the main studies in published reports. Cases of ulcerative colitis and ulcerative proctitis were pooled together. For each Departement, population data by age and sex were obtained for each year from linear interpolation of the 1982 and 1990 National Population Census. Age standardisation was done using the world standard population weights $22,18,16,12$, $12,9,7,3,1$ for each 10 year age group. ${ }^{16}$ Confidence intervals for the age adjusted rates were calculated according to the method proposed by Breslow and Day. ${ }^{17}$

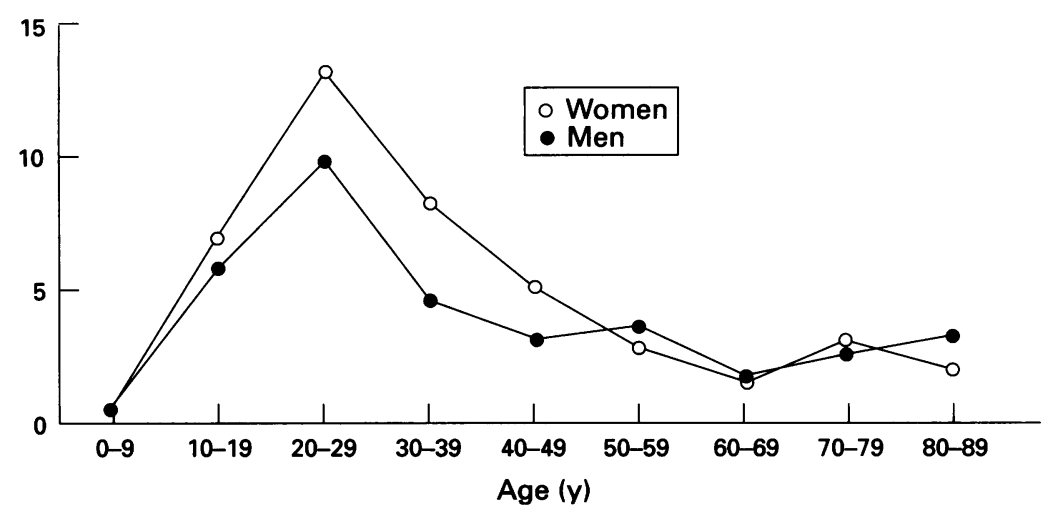

Figure 2: Incidence of Crohn's disease by sex and age in northern France (1988-1990).

\section{STATISTICS}

The incidence analysis was carried out using the Poisson model weighted with the reciprocal of the variances. Group comparisons were performed with the Wilcoxon rank sum test or Kruskal-Wallis test. The distributions of categorical data were compared with the $\chi^{2}$ or Fisher's exact test. Data analysis was performed with SAS software. ${ }^{18}$

\section{Results}

\section{INCIDENCE}

From 1988 to 1990,1291 cases of IBD were recorded. There were 674 (52\%) Crohn's disease, $466(36 \%)$ ulcerative colitis including 162 ulcerative proctitis (35\% of ulcerative colitis) and $151(12 \%)$ unclassifiable chronic colitis. Among the 674 Crohn's disease, 242 $(36 \%)$ were definite and $432(64 \%)$ probable. Among the 466 ulcerative colitis, 332 (71\%) were definite and $134(29 \%)$ probable. The mean annual incidence was 4.9 per 100000 for Crohn's disease and 3.2 for ulcerative colitis. The incidence rates of Crohn's disease and ulcerative colitis were the same for each of the three years.

Table I shows the annual incidence of IBD by sex and Departement of residence. Crohn's disease incidence in the female population was significantly higher (sex ratio $=1.3 ; \mathrm{p}<0.001$ ). In contrast, ulcerative colitis incidence in the female population was significantly lower (sex ratio $=0.8 ; \mathrm{p}<0.01$ ).

The highest age specific incidence rate for Crohn's disease was between 20 and 29 years in both sexes: 13.1 for women and 9.8 for men (Fig 2). The highest age specific incidence rate of ulcerative colitis was between 20 and 39 years in both sexes: 5.5 for women and 6.5 for men (Fig 3). There were no significant peaks in the seventh or in the eighth decade of life in both Crohn's disease and ulcerative colitis.

\section{MANIFESTATIONS OF DISEASE}

The median age at the time of the onset of clinical diagnosis was significantly higher for ulcerative colitis ( 34.3 years) than for Crohn's disease $(26.5 ; p=0.001)$. The interval from onset of symptoms to diagnosis between Crohn's disease and ulcerative colitis was significantly different $(p<0 \cdot 02)$. Crohn's disease diagnosis was made in $49 \%$ of cases before the fourth month and in $22 \%$ after the first year. Ulcerative colitis diagnosis was made earlier: $55 \%$ before the fourth month and only $14 \%$ after the first year. Seventy seven per cent of IBD (71\% of Crohn's disease and $87 \%$ of ulcerative colitis) were diagnosed and recorded by private gastroenterologists, the remainder being diagnosed by gastroenterologists in hospital practice.

In Crohn's disease, the ileum was involved in three quarters of the patients. Seventy three (11\%) patients had an isolated small bowel involvement; 131 (19\%) large bowel only; 325 $(48 \%)$ combined small and large bowel; and in $22 \%$ of the patients, examination of the small 


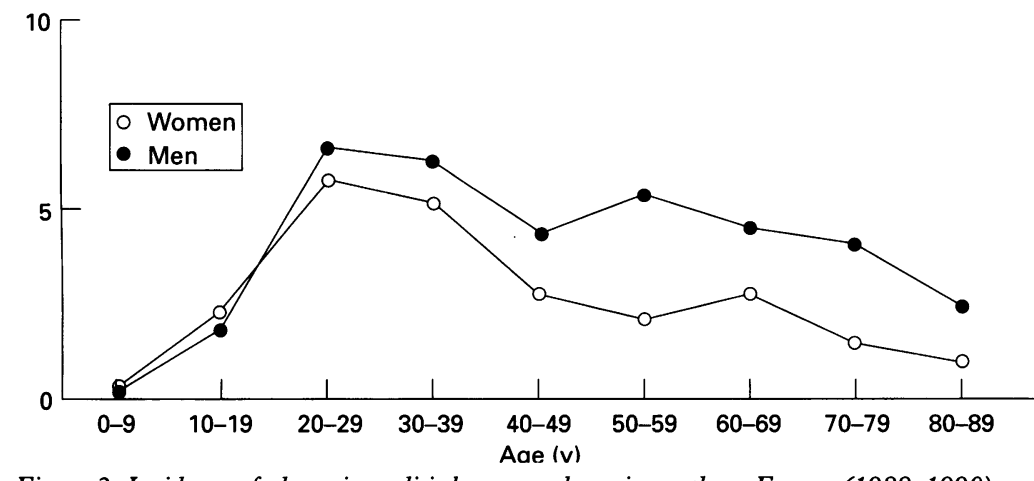

Figure 3: Incidence of ulcerative colitis by sex and age in northern France (1988-1990).

bowel was not available. Twenty per cent of the patients had perineal lesions. This pattern of distribution was found to be equal in both sexes. Patients with small and large bowel involvement were significantly younger than the other groups (median age: 23.8 in small and large bowel $v 27$ in small bowel and 28 in large bowel; $\mathrm{p}=0.001)$.

In ulcerative colitis, $35 \%$ of the patients had an ulcerative proctitis, $45 \%$ a left ulcerative colitis, $10 \%$ a pancolitis, and in $10 \%$, the examination of the large bowel was not complete. Patients with ulcerative proctitis were significantly younger (median age: 31.9 in ulcerative proctitis $v 35.7$ in ulcerative colitis; $p=0.01)$. The median interval from onset of the symptoms to the diagnosis was the same whatever the localisation of the ulcerative colitis.

\section{Discussion}

This prospective study has shown a higher annual incidence of Crohn's disease (4.9 per 100000 ) in northern France than of ulcerative colitis, which was registered simultaneously (3.2 per 100000$)$.

Whereas Crohn's disease incidence rate, in our region, was comparable with those from other studies, ulcerative colitis incidence rate was somewhat lower (Table II). Thus, in contrast with other population based studies, the ulcerative colitis/Crohn's disease ratio was $0 \cdot 65$. We think that this ratio is a valid one and not secondary to an under-registration of ulcerative colitis for the following reasons.

Our region was suitable for such a study because: (a) it included 4514055 inhabitants, permitting the collection of a sufficient number of IBD cases over three years; (b) this population was stable in a well defined geographical area (emigration rates were 0.8 for Nord,

TABLE II Incidence of ulcerative colitis in various geographical areas of the world

\begin{tabular}{rllc}
\hline Reference & Country & $\begin{array}{l}\text { Study } \\
\text { period }\end{array}$ & $\begin{array}{l}\text { Incidence } \\
\text { per 100000 }\end{array}$ \\
\hline 19 & Germany & $1970-84$ & $1 \cdot 5$ \\
& France & $1988-90$ & $3 \cdot 2$ \\
9 & Sweden & $1975-79$ & $4 \cdot 3$ \\
13 & The Netherlands & $1977-81$ & $6 \cdot 6$ \\
10 & Denmark & $1962-78$ & $8 \cdot 1$ \\
4 & Sweden & $1965-83$ & $10 \cdot 1$ \\
20 & USA & $1960-79$ & $13 \cdot 6$ \\
21 & Norway & $1984-85$ & $14 \cdot 8$ \\
\hline
\end{tabular}

All were population based studies.
0.9 for Pas de Calais, and 1.2 for Somme); (c) people in this region rarely receive medical care elsewhere (between 2.2 and $8 \%$ in our study); (d) because of its location in the north of Europe, this region was considered to be in an exposed area for IBD.

Our methodology was specifically tailored for the French Medical Care System, which is a mixture of private and public practice. Our study was not feasible without including all private gastroenterologists who represent $86 \%$ of all the gastroenterologists of the region. This study would have been biased if only hospital based. Accordingly the main hypothesis of our study design was that all patients with IBD consult a gastroenterologist. This assumption was based on the fact that in France only gastroenterologists perform endoscopies. As a consequence general practitioners refer suspected cases of IBD exclusively to gastroenterologists. The validity of our assumption was confirmed by a validation study, which established the completeness of our case collection through the gastroenterologists. In a $10 \%$ population sample (Somme Departement), a one year validation study showed that the completeness of case ascertainment by referral to gastroenterologists, was $96.5 \%$. Moreover the incidence of ulcerative colitis was found identically low in this sample despite the fact that all general practitioners and specialists of the area were included in the registration system. Indeed, the participation of private gastroenterologists was likely to be excellent in the entire study population, because $87 \%$ of all incident ulcerative colitis were notified by private gastroenterologists and $13 \%$ by gastroenterologists in hospital practice. Ulcerative colitis incidence was lower than that of Crohn's disease during each of the three years and in each of the three Departements.

The diagnosis criteria adhered to, including clinical history, radiological, endoscopic, and histological findings, were similar to those advocated by other authors, ${ }^{7} 1022$ including Lennard-Jones, which have recently been shown to be sufficient to ensure a high degree of accuracy in diagnosis. ${ }^{23}$

Our figures were calculated based only on definite and probable IBD cases according to our criteria. This could potentially result in an under-registration of incident cases. We thought, however, that including all possible cases would have led to an overestimation of incident cases. Only a follow up of possible cases will permit the calculation of the proportion of actual total IBD incident cases.

The proportion of ulcerative proctitis among incident cases of ulcerative colitis, is considered to be a good marker of the completeness of the ulcerative colitis collection. ${ }^{24}$ In our study, $35 \%$ of ulcerative colitis were ulcerative proctitis. This proportion is within the range $(25-50 \%)$ of those published in most population based studies reporting a higher ulcerative colitis incidence. ${ }^{9102526}$ Sonnenberg et al have established an international correlation between Crohn's disease 
TABLE III Incidence of Crohn's disease in various geographical areas of the world

\begin{tabular}{lllll}
\hline & & \multicolumn{3}{c}{ Incidence } \\
Reference & Country & $\begin{array}{l}\text { Study } \\
\text { period }\end{array}$ & $\begin{array}{l}\text { 100000 } \\
\text { Population }\end{array}$ \\
\hline 43 & Finland & $1975-85$ & $2 \cdot 3$ & Hospital \\
44 & Italy & $1986-87$ & $2 \cdot 7$ & Hospital \\
45 & Norway & $1976-80$ & $3 \cdot 5$ & Hospital \\
37 & USA & $1978-82$ & $3 \cdot 9$ & Hospital \\
13 & The Netherlands & $1979-83$ & $3 \cdot 9$ & Population \\
46 & USA & $1980-89$ & $3 \cdot 9$ & Hospital \\
47 & Denmark & $1979-87$ & $4 \cdot 1$ & Population \\
48 & Italy & $1990-91$ & $4 \cdot 5$ & Population \\
49 & England & $1987-90$ & $4 \cdot 9$ & Hospital \\
& France & $1988-90$ & $4 \cdot 9$ & Population \\
50 & Norway & $1984-85$ & $5 \cdot 3$ & Population \\
51 & Norway & $1983-86$ & $5 \cdot 8$ & Population \\
4 & Sweden & $1965-83$ & $6 \cdot 1$ & Population \\
38 & England & $1976-80$ & $6 \cdot 1$ & Population \\
42 & England & $1981-85$ & $6 \cdot 7$ & Population \\
41 & Scotland & $1955-85$ & $5 \cdot 4$ & Population \\
& & $1985-87$ & $9 \cdot 8$ & Population \\
\hline
\end{tabular}

and ulcerative colitis death rates. In contrast with other countries, in this study, the death rate of ulcerative colitis was lower than that of Crohn's disease in France. ${ }^{27} 28$ Finally we also registered patients with a case history of colitis dating less than six weeks. One hundred and four such cases of acute colitis were diagnosed in 1988 and were followed up for three years in Nord and Pas de Calais Departements. Among these 104 acute colitis, 21 had to be reclassified as ulcerative colitis later in the disease course. By including these new cases, ulcerative colitis incidence rate increased for 1988 from $3 \cdot 3$ to 3.9 , but remained lower than the Crohn's disease incidence rate. ${ }^{29}$

As active smoking decreases the risk of developing ulcerative colitis, ${ }^{30-33}$ high cigarette smoking could explain this low ulcerative colitis incidence. In another international epidemiological study of risk factors for myocardial infarction (Monica study) smoking habits in northern France were evaluated. ${ }^{34}$ The frequency of regular smokers in northern France $(39 \%)$ was higher than in northern Sweden (24\%) and in Goteborg (32\%), but was lower than in Scotland (52\%), all areas in which ulcerative colitis incidence were reported as being higher than Crohn's disease incidence.

The low ulcerative colitis incidence could be related to a different genetic background in the northern France population. Shanahan et al have shown a significantly increased frequency of positive p-anti-neutrophil cytoplasm antibodies ( $p$-ANCAs) among unaffected relatives of patients with ulcerative colitis compared with controls. ${ }^{35}$ They have proposed that this subclinical marker could point to a genetic susceptibility to ulcerative colitis. In our region, no p-ANCAs were found in the first degree relatives of patients with ulcerative colitis, suggesting a different genetic background in our population. ${ }^{36}$

Main epidemiological data in our population are in accordance with those previously published in studies from Europe and North America. For Crohn's disease, the age distribution and sex ratio of our study were similar to those of other studies with a peak incidence between 20 and 29 years of age and a slight increase of incidence in women.481037-40
There were no significant peaks in the seventh or eighth decade of life in Crohn's disease, as reported in some recent studies. ${ }^{102032}$ The ileum was the most common location $(59 \%)^{7} 103941$ and $48 \%$ of the patients had both large and small bowel involvement. Patients with only large bowel involvement were significantly older than those with small and large bowel involvement as reported in a study from Derby. ${ }^{42}$

In Crohn's disease, population based studies from England and north Europe disclosed results comparable with ours (Table III). Some hospital based studies reported lower incidence rates. ${ }^{3743-4649}$ As only $29 \%$ of Crohn's disease cases in our study were recorded by hospitals, it is our opinion that the main reason for the difference between other studies and ours is their design. Similarly, for ulcerative colitis, some studies excluded cases of ulcerative proctitis, and others did not distinguish between ulcerative proctitis and extensive colitis. ${ }^{1051}$

Further specific studies are needed to discover those factors responsible for a lower ulcerative colitis incidence in northern France.

This study was supported by the Observatoire Regional de la Santé du Nord Pas de Calais, the Association F Aupetit, the Caisse Regionale d'Assurance Maladie de Nord-Picardie, the Ministère de la Santé et de l'Action Humanitaire (Direction Générale de la Santé), the INSERM, and the Smith Kline French and Ferring Companies.

We thank all the gastroenterologists and all specialists who had participated in this study. Armand A, Andre J M, Awada J, Barbry B, Becqwort J P, Bertaux D, Bertrand M, Biron-
Verplanck N, Bleuez M, Binot D, Boniface E, Bonniere Ph, Bonvarlet P, Bonvarlet F, Borie J P, Bostvironnois R Boudaillez Ch, Bourneville M, Bray G, Breban P, Buffin R P, Butel J, Capron D, Capron J P, Carpentier P, Catteau S, Chambon J P, Chantre M, Charles J, Claerbout JF, Cohen G, Collet R, Crinquette J F, Cuvelier A, Davion Th, Debat J, Decroix B, Degrave N, Dehon F, Delalaing P, Delattre-Becuwe C, Delcenserié R, Delette O, Delgrange Th, Delhoustal L, Delmotte JS, Deregnaucourt G, Descombes Ph, Desmet P,
Desseaux G, Desurmont Ph, Devienne A, Devred M, Dewailly Desseaux G, Desurmont $P$, Devienne A, Devred $M$, Dewailly E, Doutriaux M, Druart R, Dubois R, Ducatillon Ph, Ducroca B, Dujardin B, Dupas J L, Dupond F, Farriaux J P, Feydy P, Filoche B, Foutrein Ph, Gallais Ph, Gamblin C, Gerard A, Gower Ph, Grandmaison B, Guillemot F, Hanon D, Hazard C,
Hecquet G, Hedde J P, Heraud M, Heyman B, Houcke Ph, Hecquet G, Hedde J P, Heraud M, Heyman B, Houcke Ph, Janicki E, Jeu J F, Joly J P, Jonas C, Julien C, Kerleveo A,
Kornhauser R, Laffineur G, Lannoy P, Lapchin J, Laprand M, Laude D, Lecieux P, Ledent J, Lefebvre J, Lelarge C, Lelong P, Leplat A, Leroi H, Lesage J P, Lesage X, Lescanne-Darchis I, Lescut D, Lescut J, Leurent B, Lhermie M, Lion A, Lisambert B, Luez J, Lugand J J, Macaigne O, Maetz D, Malakhia C, Mancheron H, Marti R, Martin G, Martin F, Marzlof E, Mathieu-Chandelier C, Maunoury V, Meignie $P$ , Mathieu-Chandelier C, Maunoury V, Meignie $P$, Messerchmidt J, Mesnard B, Meurisse B, Morel L, Mudry J Ostyn A, Papazian A, Paris J C, Pauwels B, Petit J, Plane Ch, Plouvier B, Pollet E, Pommelet P, Pouchain G, Prades Ph Prevost A, Proye C, Pruvost FR, Quandalle P, Rabelle P, Reix N, Ribet M, Richard P, Roger J, Roux J M, Rudelli A Schlossberg P, Serin M, Sevenet F, Sevestre H, Silvie J, Simon V, Spyckerelle C, Thelu J L, Thevenin A, Thiry P, Thomas C Toison G, Tonnel J, Tossou H, Triboulet J P, Triplet C, Turck $\mathrm{D}$, Valmage $\mathrm{Ph}$, Vanco D, Vanderbecque E, Vandermolen $\mathrm{Ph}$ Vandevenne $\mathrm{Ph}$, Vanhoove J $\mathrm{P}$, Vankemmel $\mathrm{M}$, Varlet $\mathrm{Ph}$ Verbiese G, Vermelle $\mathrm{Ph}$, Vincendet $M$, Viot J, Voiment $Y \mathbf{M}$, Voreux J P, Waghemacker Ph, Wallez J Y, Wantiez M, Weber J, Willocquet J L, Wohlschies E, Wurtz A, Zellweger A.

1 Evans J G, Acheson ED. An epidemiological study of ulcerative colitis and regional enteritis in the Oxford area. Gut 1965; 6: 311-24.

2 Gilat T, Ribak J, Benaroya Y, Zemishlany Z, Weissman I. Ulcerative colitis in the Jewish population of Tel AvivJafo. Gastroenterology 1974; 66: 335-42.

3 Norlen BJ, Krause U, Bergman L. An epidemiological study of Crohn's disease. Scand $¥$ Gastroenterol 1970; 5: 385-90

4 Ekbom A, Helmick C, Zack M, Adami HO. The epidemiology of inflammatory bowel disease: a large population based study in Sweden. Gastroenterology 1991; 100: 350-8.

5 Berner J, Kjaer T. Ulcerative colitis and Crohn's disease on the Faroe Island 1964 to 1983 . Scand $\mathcal{F}$ Gastroenterol 1986; 21: 188-92. 
6 Devlin HB, Datta D, Dellipiani AW. The incidence and prevalence of inflammatory bowel disease in North Tees prevalth district. World 7 Surg 1980; 4: 183-93.

7 Calkins BM, Lilienfeld AM, Garland CF, Mendeloff AI Trends in incidence rates of ulcerative colitis and Crohn's disease. Dig Dis Sci 1984; 29: 913-20.

8 Brahme F, Lindstrom C, Wenckert A. Crohn's disease in a defined population: an epidemiological study of incidence, prevalence, mortality and secular trends in the city of Malmo, Sweden. Gastroenterology 1975; 69: 342-51.

9 Nordenvall B, Brostrom O, Berglund $M$, Monsen U, Nordenstrom J, Sorstad J, et al. Incidence of ulcerative colitis in Stockholm county 1955-79. Scand Gastroenterol 1985; 20: 783-90.

10 Binder V, Both H, Hansen PK, Hendriksen C, Kreiner S, Torp-Pedersen $\mathrm{K}$. Incidence and prevalence of ulcerative colitis and Crohn's disease in the county of Copenhagen 1962 to 1978 . Gastroenterology 1982; 83: 563-8.

11 Sedlack RE, Norbrega FT, Kurland LT, Sauer WG. Inlammatory colon disease in Rochester, Minnesota 1935 to 1964 . Gastroenterology 1972; 62: 935-41.

12 Garland CF, Lilienfeld AM, Mendeloff AI, Markowitz JA, Terrell KB, Garland FC. Incidence rates of ulcerative colitis in fifteen areas of the United States. Gastroenterology 1981; 81: 1115-24.

13 Shivananda AS, Pena AS, Nap M, Weterman IT, Mayberry JF, Ruitenberg EJ, et al. Epidemiology of Crohn's disease in Regio Leiden, Netherlands - a population study. Gastroenterology 1987; 93: 966-74.

14 Sedlack RE, Whisnant J, Elveback LR, Kurland LT Incidence of Crohn's disease in Olmsted county, Minnesota 1935-1975. Am f Epidemiol 1980; 112: 759-63.

15 Sonnenberg A, Mac Carty DJ, Jacobsen SJ. Geographic variation of inflammatory bowel disease within the United States. Gastroenterology 1991; 100: 143-9.

16 Waterhouse J, Muire C, Correa P, Powel J. Cancer incidence in five continents. IARC Sci Publ 1976; 3: 454-9.

17 Breslow NE, Day NE. The design and analysis of cohor studies. In: IARC ed. Statistical methods in cancer research. Vol 2. Lyon: IARC, 1987: 48-79.

18 SAS Institute INC. SAS/STAT user's guide. Version 6, 4th ed. Cary, NC: SAS Institute INC, 1989

19 Daiss W, Scheurlen M, Malchow H. Epidemiology of inflammatory bowel disease in the county of Tubingen (Germany). Scand f Gastroenterol 1989; 24 (suppl 170): 39-43.

20 Stonnington CM, Phillips SF, Melton LJ, Zinsmeister AR. Chronic ulcerative colitis: incidence and prevalence in community. Gut 1987; 28: 402-9.

21 Haug K, Schrumpf E, Barstad S, Fluge G, Halvorsen JF, and the study group of inflammatory bowel disease in western Norway. Epidemiology of ulcerative colitis in western Norway. Scand $\mathcal{F}$ Gastroenterol 1988; 23. 517-22.

22 Lennard-Jones JE. Classification of inflammatory bowel disease. Scand f Gastroenterol 1989; suppl 24: 2-4.

23 Shivananda S, Hordijk ML, Ten Kate FJW, Probert CSJ, Mayberry JF. Differential diagnosis of inflammatory bowel disease. A comparison of various diagnostic classifications. Scand f Gastroenterol 1991; 26: 167-73.

24 Mendeloff AI, Calkins B. The epidemiology of inflammatory bowel disease. In: Kirsner JB, Shorter RG, eds. Inflammatory bowel disease. Philadelphia: Lea and Inflammatory bowel

25 Samuelsson SM. Ulceros colit och proctit [Thesis]. Uppsala: Department of social medicine, University of Uppsala, 1976

26 Ritchie JK, Powell-Tuck J, Lennard-Jones JE. Clinical outcome of the first ten years of ulcerative colitis and proctitis. Lancet 1978; i: 1140-3.

27 Sonnenberg A. Geographic variation in the incidence of and mortality from inflammatory bowel disease. Dis Colon Rectum 1986; 29: 854-61.

28 Mendeloff AI. The epidemiology of chronic inflammatory bowel disease. In: Jarnerot $G$, Lennard-Jones J, Truelove
S, eds. Inflammatory bowel disease. Malmö: Corona/Astra, 1992: 15-35.

29 Nottegham B, Salomez JL Gower-Rousseau C, Marti R, Lemahieu M, Nuttens MC, et al. Que deviennent les colites aigues inclassées? Resultats d'une étude de cohorte de 104 malades dans la region Nord Pas de Calais Gastroenterol Clin Biol 1993; 11: 811-6.

30 Jick $\mathrm{H}$, Walker AM. Cigarette smoking and ulcerative colitis. N Engl f Med 1983; 308: 261-3

31 Benoni C, Nilsson A. Smoking habits in patients with inflammatory bowel disease. Scand f Gastroenterol 1984; 19: 824-30.

32 Boyko EJ, Koepsell TD, Perera DR, Inui TS. Risk of ulcerative colitis among former and current cigarette smokers. $N$ Engl f Med 1987; 31: 707-10.

33 Tobin MV, Logen RFA, Langman MJS, McConnell RB Gilmore IT. Cigarette smoking and inflammatory bowel Gilmore IT. Cigarette smoking and inflam

34 The WHO MONICA project. A worldwide monitorin system for cardiovascular diseases. World Health Stat Annual 1989: 27-59.

35 Shanahan F, Duerr RH, Rotter JI, Yang H, Sutherland LR, McElree C, et al. Neutrophil autoantibodies in ulcerative colitis: familial agregation and genetic heterogeneity. Gastroenterology 1992; 103: 456-62.

36 Reumaux D, Delecourt L, Colombel JF, Noel LH, Duthilleul P, Cortot A. Anti neutrophil cytoplasmic autoantibodies in relatives of patients with ulcerative colitis. Gastroenterology 1992; 103: 1706.

37 Gollop JH, Phillips SF, Melton LJ, Zinsmeister AR. Epidemiologic aspects of Crohn's disease: a population Epidemiologic aspects of Crohn's disease: a population Gut 1988; 29: 49-56.

38 Lee FI, Costello FT. Crohn's disease in Blackpool - incidence and prevalence 1968-80. Gut 1985; 26: 274-8.

39 Hellers G. Crohn's disease in Stockholm county, 1955-1974. Acta Chir Scand Suppl 1979; 490: 1-84.

40 Bergman L, Krause U. The incidence of Crohn's disease in central Sweden. Scand f Gastroenterol 1975; 10: 725-9.

41 Kyle J. Crohn's disease in the Northeastern and Northern sles of Scotland: an epidemiological review. Gastroenterology 1992; 103: 392-9.

42 Fellows IW, Freeman JG, Holmes GKT. Crohn's disease in the city of Derby, 1951-85. Gut 1990; 31: 1262-5.

43 Halme L, von Smitten K, Husa A. The incidence of Crohn's disease in the Helsinki Metropolitan area during 1975-1985. Ann Chir Gynaecol 1989; 78: 115-9.

44 Amanta E, Barbara L, Biasco C. Incidence and prevalence of inflammatory bowel disease in Bologna-risk factors. Scand $\mathcal{F}$ Gastroenterol 1989; 24 (suppl): 158-63.

45 Skarstein A, Arnesjo B, Burhol P. The incidence of ulcerative colitis and Crohn's disease in an urban population. Scand $\mathcal{F}$ Gastroenterol 1982; 17 (suppl 78): 349

46 Stowe SP, Redmond SR, Stormont JM, Shah AN, Chessin LN, Segal HL, et al. An epidemiologic study of inflammatory bowel disease in Rochester, New York. Gastroenterology 1990; 98: 104-10.

47 Munkholm P, Langholz E, Haagen Nielsen O, Kreiner S, Binder V. Incidence and prevalence of Crohn's disease in the County of Copenhagen, 1962-87: a sixfold increase in incidence. Scand $¥$ Gastroenterol 1992; 27: 609-14.

48 Ranzi T, Campanini MC, Lisciandrano D, Bodini $P$, Zambelli A, Lupinacci G, et al. Incidence of IBD in a defined area of Northern Italy: a four-year prospective defined area of Northern Italy: a four-year prospect

49 Rose JDR, Roberts GM, Williams A, Mayberry JF, Rhode J. Cardiff Crohn's disease jubilee: The incidence over 50 years. Gut 1988; 29: 346-51

50 Haug K, Schrumpf E, Halvorsen JF, Fluge G, Hamre E, Hamre $\mathrm{T}$, et al. Epidemiology of Crohn's disease in Western Norway. Scand f Gastroenterol 1989; 24: 1271-5.

51 Kildebo S, Brackan R, Nordgaard K, Burhol PG, Jorde R, and members of the Northern Norway Gastroenterology Society. The incidence of Crohn's disease in Northern Norway from 1983 to 1986 . Scand $\mathcal{F}$ Gastroenterol 1989; 24: $1265-70$. 